\title{
Economic Institutions and FDI Location Choice: Evidence from U.S. Multinationals in China
}

\author{
Julan Du, Yi Lu and Zhigang Tao ${ }^{1}$
}

March 2007

\footnotetext{
${ }^{1}$ From the Chinese University of Hong Kong, University of Hong Kong and University of Hong Kong respectively. Corresponding author: Zhigang Tao, School of Business, University of Hong Kong, Pokfulam Road, Hong Kong. Telephone: (852)-2857-8223; Fax: (852)-2858-5614; Email: ztao@hku.hk. We appreciate comments and suggestions from participants at 2006 Industrial Organization and Strategy Conference at Peking University, and 2006 East Asian Economic Association meeting. Financial support from Hong Kong Institute of Economics and Business Strategy is acknowledged.
} 


\title{
Economic Institutions and FDI Location Choice: Evidence from U.S. Multinationals in China
}

\begin{abstract}
This paper examines the impacts of economic institutions, including property rights protection and contract enforcement, on the location choice of foreign direct investment. From a data set of 6,288 U.S. multinationals investing in various China's regions for the period of 1993-2001, it is found that U.S. multinationals prefer to invest in those regions that have better protection of intellectual property rights, lower degree of government intervention in business operations, lower level of government corruption, and better contract enforcement. Our results are robust to alternative measures of economic institutions, and to the inclusion of control variables such as those for agglomeration economies, and other traditional factors of FDI location choice.
\end{abstract}

\section{Introduction}

Foreign direct investment (FDI) is one of the driving forces behind the development of transition economies. China provides an example. Since 1978, it has attracted more than US $\$ 500$ billion foreign direct investment (China Statistical Yearbook, 2005), and the World Bank (1997) has credited FDI as a key factor to China's economic growth during this period. This is why those transition economies give top priority to attracting FDI and show tremendous interests in understanding what helps lure FDI. Like any investment, the incentive for multinationals to invest in those transition economies depends on their expected returns. In transition economies, investment returns depend critically on the protection of property rights (the vertical relations between the state and owners of private properties) and contract enforcement (the horizontal relations between transacting parties), the two of which are referred to as economic institutions (Acemoglu and Johnson, 2005). Thus, an important research question is to investigate the impacts of economic institutions on foreign direct investment.

In recent years, there emerges an important literature about the impacts of economic institutions on investment incentives and economic performance. ${ }^{1}$ The studies of the impact of economic institutions on FDI flows are, however, rather limited. In a cross-country study using bilateral FDI

\footnotetext{
${ }^{1}$ See, among others, Besley (1995), Knack and Keefer (1995, 1997), Mauro (1995), Hall and Jones (1999), La Porta, Lopez-De-Silanes, Shleifer and Vishny (1999), Acemoglu, Johnson, and Robinson (2001, 2002). For a brief review, please read Pande and Udry (2005).
} 
flows data, Wei (2000a, 2000b) finds that corruption in a host country substantially deters inward FDI. Campos and Kinoshita (2003) use an aggregate panel data set for twenty-five transition economies from Central Europe and the former Soviet Union to show that institutions, mainly reflected in rule of law and quality of bureaucracy, are an important determinant of FDI flows. Such cross-country studies have difficulties controlling for the impacts of political system, culture and language, corporate tax policies, and national trade and investment policies that could vary dramatically across countries. Furthermore, the use of aggregated FDI flows as some of the cross-country studies did makes it impossible to control for the identity of foreign investors, which may interact with the economic institutions of the host countries. To overcome these two issues, in this paper, we study the impacts of economic institutions on FDI location choice made by U.S. multinationals in China's various regions.

China is a unitary state with uniform de jure laws across the country. However, China is characterized by substantial regional disparity in economic institutions, i.e., the de facto property rights protection and contract enforcement exhibit wide variations across regions. In this sense, examining the cross-region variation in economic institutions in China allows us to conduct a natural experiment to focus on the de facto law enforcement after holding constant the de jure legal codes. This certainly offers a better setting to distinguish between legal codes and law enforcement than the cross-country analysis does. Meanwhile, the United States (U.S.) is the third largest FDI source country/region in China after Hong Kong and Taiwan. Compared with Hong Kong and Taiwan, investment from the U.S. is viewed as "truly foreign" in nature, because Hong Kong and Taiwan are ethnically Chinese economies and some of the investment from these two economies are originated from mainland China for tax and other reasons (so-called round-trip FDI). More importantly, FDI from the U.S. could be particularly vulnerable to weak economic institutions because of the 1977 Foreign Corrupt Practices Act that prohibits U.S. multinationals from bribing local officials in overseas investment (Bardhan, 1997). Hence, it is ideal to use FDI from the U.S. to explore the effects of economic institutions on FDI.

Specifically, we construct indices for property rights protection (including the extent of intellectual property rights protection, the degree of government intervention in business operations, and the level of government corruption) and contract enforcement (the effectiveness of courts in dispute resolution). Three of these indices are based on a survey of private enterprises in China. Unlike state-owned or collectively-owned enterprises under the auspices of governments, private enterprises have to fight for survival and growth by themselves. Their views of the role played by governments in en- 
suring a reasonable business environment could reflect the reality to a large extent. We employ the discrete choice model developed by McFadden (1974) to examine the impacts of economic institutions on FDI location choice made by 6,288 U.S. multinationals investing in various regions in China for the period of 1993-2001. Our empirical analysis shows that regions with stronger economic institutions are more likely to attract U.S.-based multinational enterprises (MNEs) to set up business operations in those regions.

There is a large literature on the determinants of FDI location choice, including wage costs, infrastructure, and market potential. An important focus of this literature is about the effect of agglomeration on FDI location choice. For example, Head, Ries and Swenson (1995) show that there do exist agglomeration effects of Japanese manufacturing firms in the United States. ${ }^{2}$ There is also a large literature on FDI location choice in China. Belderbos and Carree (2002), Fung, Iizaka and Parker (2002), and Fung, Iizaka and Siu (2003) examine a host of traditional FDI location determinants. Head and Ries (1996), Cheng and Kwan (2000), He (2002), Chang and Park (2005), and Amiti and Javorcki (2007) focus on the effects of agglomeration in FDI location choice in China. The focus of our paper is on the impacts of economic institutions on FDI location choice. Our main results are still robust, even after controlling for the agglomeration effect and other traditional determinants of FDI location choice.

The rest of the paper is organized as follows. Data and variables are described in Section 2. Empirical estimation strategy and results are discussed in Section 3. Section 4 concludes the paper.

\section{Data and Variables}

\subsection{Data}

The largest source countries/regions of FDI to China are Hong Kong, Taiwan, United States, Japan and South Korea in descending order. Though Hong Kong and Taiwan claim the largest shares of FDI to the Chinese mainland, they are ethnically Chinese economies, and FDI from these two regions may not be representative of FDI in general. Meanwhile, Japan and Korea are geographically close to China, and they even share some similar cultural heritage with China. In this sense, even FIEs from Japan and Korea are not "truly foreign" enough. Thus, U.S. is the largest "truly foreign" source

\footnotetext{
${ }^{2}$ There is also evidence for agglomeration effect in FDI from data of other countries, such as Portugal by Guimaraes, Figueiredo and Woodward (2000), France by Crozet, Mayer and Mucchielli (2004), and Hungury by Boudier-Bensebaa (2005).
} 
country of FDI to China. Thus, in this study, we focus on the location choice of foreign direct investment by U.S. investors in China.

Our data come from a survey of foreign-invested enterprises (FIEs) set up by U.S. investors in China. The survey was conducted by the National Bureau of Statistics of China in 2001. There are altogether 13,290 U.S.-FIEs in the sample, accounting for around $75 \%$ of the total number of U.S.-FIEs operating in China in 2001 as reported by China Statistical Yearbook 2002.

After deleting those U.S.-FIEs without registration dates, we have 13,270 firms. As the location choice of service firms could be qualitatively different from that of manufacturing firms, we confine our analysis to the subsample of manufacturing firms set up by U.S. investors. The dataset specifies the type of investors as either individuals or companies. We focus on the FDI location choice of U.S. companies in China because the behavior of individual investors could be quite different from that of multinationals. Furthermore, we notice that a majority of U.S. individual investors are Chinese Americans who, under most circumstances, take advantage of their cultural affinity with China to set up small-scale FIEs in the Chinese mainland. This situation is much less likely for FIEs set up by U.S. companies.

After restricting our study to manufacturing firms and deleting those FIEs established by individual U.S. investors, we are left with a sample of 7,521 U.S. firms. The registration dates of these firms span from 1982 (4 years after China started its economic reform) to 2001 (the sample year). Table 1 lists the annual number of FIEs newly established by U.S. multinationals by the year of registration from 1982 to 2001. It is clear that the FDI flow from the U.S. into China has increased dramatically only since 1992. Because the data for constructing the indicators of economic institutions are only available after 1993, we further restrict our analysis to those FIEs set up by U.S. multinationals during 1993-2001, and end up with a final sample of 6,288 U.S.-FIEs. This sample period captures the majority of U.S.-FIEs engaged in manufacturing industries.

Table 2 provides a breakdown of manufacturing FIEs by U.S. multinationals across 29 different regions in China. A brief look at this table shows that the inward FDI flow from the U.S. is mainly concentrated in the coastal regions: Jiangsu, Shanghai, Shandong, Zhejiang, and Guangdong claim the largest numbers of manufacturing U.S.-FIEs in descending order, while inland regions such as Qinghai, Ningxia, Hainan, Guizhou, and Gansu have the smallest numbers of manufacturing FIEs in ascending order. ${ }^{3}$ The dependent variable for our analysis is the location choice by U.S. multinationals during

\footnotetext{
${ }^{3}$ Tibet has received no investment from U.S. multinationals during the sample period, and is excluded in our conditional logit analysis.
} 
the sample period of 1993-2001.

\subsection{Variables}

At least since Smith (1776), the economics profession has reached a consensus: One of the government's most important responsibilities to ensure a well-functioning market economy is to protect property rights and maintain a secure contracting environment. Thus, our measures of economic institutions are about property rights protection and contract enforcement.

\subsubsection{Property Rights Protection}

\section{Intellectual Property Rights Protection}

Unlike some of the other transition economies, China did not have formal protection of private properties until fairly recently. However, various regulations and rules help maintain a reasonable level of protection for private properties, and the level of protection differs from one region to another. Thus, our measure of property rights protection intensively reflects the de facto property rights protection across China's regions. We use the protection of intellectual properties to measure property rights protection. This is ideal not only because we can rely on the quantifiable patent data in gauging intellectual property rights protection but also because it reflects the central concern of U.S. FIEs. Unlike small- and medium-sized FIEs from ethnically Chinese economies like Hong Kong and Taiwan, multinationals from the United States are typically large companies equipped with modern technologies. This is consistent with the importance of intellectual property in the American economy. According to Israel (2006), industries with significant intellectual properties account for over half of all U.S. exports; intellectual property accounts for over $1 / 3$ of the value of all U.S. corporations, and represents $40 \%$ of U.S. economic growth. It is thus not surprising that FIEs from the United States are particularly concerned with intellectual property rights protection.

In recent years, the rising tide of counterfeiting and piracy in China has posed an enormous threat to U.S. business interests. In a 2005 survey of the U.S.-China Business Council, members put enforcement of intellectual property rights protection at the very top on their list of concerns. The serious intellectual property infringement in China reflects the lack of proactive and deterrent intellectual property enforcement, especially at the local level (Israel, 2006; Stratford, 2006). Depending on the difference in government coordination capacity, corruption, staff training and legal enforcement power 
across regions, the degree of intellectual property rights protection also exhibits large variation from region to region.

We use the logarithm of the number of approved patents per capita (available from China Statistical Yearbook, various issues) as a measure of intellectual property rights protection. Though patent number could be an outcome of research and development capacity and inputs, human capital endowment and other factors in various regions, property rights protection provided by regional governments no doubt plays an important role. For example, Guangdong has a lower level of education achievements in terms of both the proportion of people enrolled in higher-education institutions and that having higher education degrees than many other regions such as Jilin and Heilongjiang, but the number of patents per capita in Guangdong is much higher than that in these two Northeastern regions. To further relieve the potential concern about whether the number of patents per capita mainly reflects regional human capital endowments, we control for the education level in various regions in China in our regression analysis.

Intellectual property rights protection varies substantially across the country. As shown in Table 3, Beijing has the highest number of patents per capita, followed by Shanghai and Guangdong, whereas Gansu has the lowest number of patents per capita and followed by Guizhou and Qinghai.

For robustness check, we use an alternative measure of intellectual property rights protection, which is a sub-index of the China Regional Marketization Indices developed by Fan, Wang and Zhu (2003). This index is constructed by combining two ratios. One is the ratio of the number of applications for various types of patent to GDP, and the other is the ratio of the number of various types of approved patent applications to GDP. Since the compilation of the Fan-Wang-Zhu index started as late as 1997, we have to restrict our analysis to the subsample of the period 1998-2001 when using this alternative index of intellectual property rights protection.

\section{Government Intervention in Business Operations}

The second variable for property rights protection concerns the degree of Government Intervention in Business Operations, constructed based on data from the survey of China's Private Enterprises 1995-2002. ${ }^{4}$ In the survey, there is a question about whether private entrepreneurs would go and ask for government help when they encounter business disputes, and the variable Government Intervention in Business Operations is defined as the proportion

\footnotetext{
${ }^{4}$ This survey was conduced by the United Front Work Department of the Central Committee of the Communist Party of China, the All China Industry and Commerce Federation, and the China Society of Private Economy at the Chinese Academy of Social Sciences, in 1995, 1997, 2000, and 2002.
} 
of entrepreneurs requesting government help in case of business disputes. This index exhibits wide variation across regions. For example, in terms of level of economic development, the six regions of Beijing, Guangdong, Jiangsu, Shanghai, Tianjin, and Zhejiang are at similar level, but they differ substantially in terms of government intervention. Beijing, Jiangsu, Tianjin and Zhejiang have a score of about 0.10 and 0.11 , Shanghai has a value of 0.07, whereas Guangdong has 0.05 that is only about half of that for Beijing etc. For more information on the variation of this index across China's regions, please read Table 3.

Government intervention in business operations could be indicative of either strong or weak protection of private properties. On the one hand, government help may fill the void created by the lack or weakness of the court system. That is to say, government intervention is a second-best solution to the lack of formal protection of private properties. If this is the case, U.S. multinationals may find government help in business operations an appealing feature of China's regional governments. On the other hand, government help may lead to rent-seeking and even corruption: entrepreneurs lobby or bribe government officials to seek favor in resolving business disputes. This becomes the grabbing hand of the government (Frye and Shleifer 1997; Shleifer and Vishny, 1999). Faced with the hand-binding law against bribing local government officials, however, the U.S. multinationals cannot enjoy the benefits of government intervention but have to bear the costs of other firms getting advantages of government help. Thus, U.S. multinationals are particularly disadvantaged in a region where there is significant government intervention in business operations.

Again, for robustness check, we use an alternative index of government interference with enterprises, a sub-index in Fan-Wang-Zhu's China Regional Marketization Indices. It is constructed on the basis of the percentage of time the enterprise managers have spent dealing with government agencies and officials.

\section{Government Corruption}

China's economic reform has been accompanied by the rampant corruption over the past three decades. The extensive state control of and state intervention in the national economy, the lack of democracy and freedom of media, the weak rule of law, etc. have contributed to the severe corruption problem. As U.S. multinationals are constrained by legal prohibition against bribery in foreign countries, we expect that they are particularly vulnerable to government corruption. Government corruption, however, varies across China's regions, which provides us an opportunity to test the impacts of the severity of government corruption on FDI by U.S. multinationals. 
From the same survey of China's Private Enterprises, we construct an indicator of the degree of Government Corruption in China's different regions. It is the proportion of private entrepreneurs answering "Yes" to the question: is it necessary to have stricter policies against government corruption in your region? ${ }^{5}$ As shown in Table 3, Guizhou has the highest degree of government corruption, followed by Hainan and Jilin, while Shanghai enjoys the lowest degree of government corruption followed by Hubei and Jiangsu. Like the cross-country corruption indices such as those constructed by Business International, Transparency International or International Country Risk Guide, our cross-region corruption measure for China is a subjective survey-based index based on entrepreneurs' perceptions of the severity of corruption.

\subsubsection{Contract Enforcement}

Contract enforcement hinges on legal institutions and law enforcement. While China has had commercial laws on paper since the early stage of its economic reform, the quality of legal institutions and the degree of law enforcement, however, vary significantly across regions. A comprehensive indicator of the effectiveness of contract enforcement is the willingness to use courts in resolving business disputes. From the survey of China's Private Enterprises, we construct a measure of Contract Enforcement in China's various regions. It is the proportion of private entrepreneurs answering affirmatively to the question: will you use courts to resolve business disputes? This index also exhibits large variation across regions. For instance, as shown in Table 3, some neighboring regions in North China, i.e., Beijing, Tianjin, Hebei and Shanxi, exhibit large variation in the value of this index, having $0.24,0.17$, 0.22 and 0.10 respectively. For an illustration of this variable for year 2000 across China's regions, please read Table 3.

In Fan-Wang-Zhu's (2003) China Regional Marketization Indices, there is a sub-index on legal institutions and contract enforcement. It is the proportion of lawyers in a region's total population. We use it as an alternative measure of contract enforcement in our robustness analysis. Again, our analysis will be restricted to the subsample of 1998-2001 when this variable is used, for it is available only after 1997.

\footnotetext{
${ }^{5}$ Because the question on the degree of government corruption was introduced only after the 1997 survey, our analysis using the "Government Corruption" index will be restricted to the subsample of the period 1998-2001.
} 


\subsubsection{Other Variables}

While our focus is on the impacts of economic institutions on FDI location choice made by U.S. multinationals, we also control for a list of other factors that have been found to be important in the literature. The most important one is agglomeration effect, including both horizontal and vertical agglomeration.

The growing literature on new economic geography focuses on knowledge spillover as the potential benefits of horizontal agglomeration (Krugman, 1991; Porter, 1998). On the other hand, agglomeration could also generate negative externalities. A firm's own knowledge and technologies can be transferred to rival firms to its disadvantages. Agglomeration may also give rise to intensified competition in both product markets and input markets among adjacently located firms.

The new economic geography theories also highlight the role of backward and forward linkages, as they promote complementarities and cooperation among firms of related production stages. The concentration of upstream firms indicates the accessibility to component suppliers in the region, whereas the concentration of downstream firms and final goods consumers shows the accessibility to market in the regions (Krugman and Venables, 1995; Venables, 1996; Duranton and Puga, 2004). Therefore producers typically like to choose locations that have good access to large markets and to suppliers of intermediate inputs. It should be pointed out that the horizontal and vertical agglomeration are often bundled together (Fujita, Krugman and Venables, 2001).

\section{Agglomeration}

Horizontal agglomeration is measured by the ratio of the number of firms in the same region and same 4-digit industry to the national total of the same 4-digit industry. Here we differentiate two types of horizontal agglomeration: the agglomeration of U.S. multinationals which is constructed based on the 2001 Survey of Foreign Invested Enterprises, and the agglomeration of China's indigenous firms based on the Annual Survey of Industrial Firms by China's National Bureau of Statistics.

$$
\begin{aligned}
\text { Agglomeration_US } S_{i r t} & =\frac{\text { Number_US } S_{i r t}}{\text { Number_US } S_{i t}} \\
\text { Agglomeration_Domestic }_{i r t} & =\frac{\text { Number_Domestic } i r t}{\text { Number_Domestic } c_{i t}}
\end{aligned}
$$

where $i$ represents industry, $r$ denotes region and $t$ indicates year. ${ }^{6}$

\footnotetext{
${ }^{6}$ Here we follow Head, Ries, and Swenson (1995) in considering the degree of horizontal
} 
For a given 4-digit industry and a given region, the degree of vertical agglomeration is measured by the concentration of upstream or downstream firms in the same region, weighted by the degree of linkages between the industry and those upstream or downstream industries. Specifically the backward (i.e., upstream industries) and forward (i.e., downstream industries) agglomerations are defined as

$$
\begin{aligned}
& \text { Backward }_{i r t}=\sum_{j} \alpha_{i j} \frac{\text { Number_domestic }}{\text { jrt }}
\end{aligned}
$$

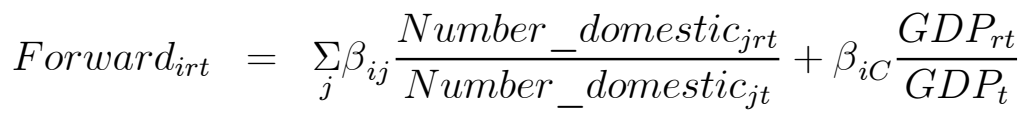

where $\alpha_{i j}$ is the input-output ratio reflecting the inputs from the upstream industry $j$ required for one unit of output of industry $i ; \beta_{i j}$ is the inputoutput ratio showing the input made by industry $i$ required for one unit of output of downstream industry $j$; and $\beta_{i C} \frac{G D P_{r t}}{G D P_{t}}$ indicates the proportion of final demand for industry $i$ 's output by region $r$ in the total final demand by the whole country. ${ }^{7}$ The data used for constructing the indices for vertical agglomeration come from the Annual Survey of Industrial Firms by China's National Bureau of Statistics and the 1997 Input-Output Table of China. ${ }^{8}$

\section{Other Regional Characteristics as Control Variables}

We follow the literature on FDI location choice to control for the following factors in regression analysis.

(1) Wages. Low production costs mainly reflected in low wages are widely regarded as an advantage of China in attracting foreign manufacturing firms. To see how the regional differentiation in wage costs affects FDI distribution, we include in our analysis the average manufacturing wages in each region. ${ }^{9}$

(2) Infrastructure. It is widely reported in the literature that regions with superior transportation facilities are more appealing to FIEs. We use highway density, i.e., the length of highway per square kilometer in a region, as an indicator of infrastructure adequacy.

agglomeration of both indigenous firms and firms from the same source country.

${ }^{7}$ Here we employ regional GDP to proxy for market demand and use the ratio of regional GDP to national GDP to indicate the share of final demand accounted for by some particular region.

${ }^{8}$ Our backward and forward agglomeration indicators are similar in nature to the supplier access and market access measures respectively adopted in Amiti and Javorcki (2007). In their work, industry output is used to gauge the market access and supplier access, while we use the number of firms instead because of data limitation. They have also consider the effect of distance on the impacts of agglomeration economies.

${ }^{9}$ Data sources for the five variables are listed in the Appendix A1. 
(3) Education. The average human capital level of the workforce could be an important determinant of FDI location for U.S. multinationals, as they tend to be engaged in technology-intensive industries. We therefore use the proportion of the number of students enrolled in higher education institutions in a region to its total population as a proxy for the average level of human capital in the region.

(4) Presence of U.S. embassy or consulates. The United States has its embassy in Beijing, and consulates in Chengdu, Guangzhou, Shanghai and Shenyang. U.S. embassy and consulates could play an important role in facilitating information transmission to U.S. multinationals regarding national and regional situations, which could help them overcome various informational and cultural barriers to making investments in China. We therefore include a dummy variable taking value one if there is U.S. embassy or consulate in a region and zero otherwise.

(5) Government promotion policies. The Chinese central government and the local governments at various levels set up a large variety of promotion policies to attract FDI. One important aspect of these promotion policies is establishing different types of special development zones. At the national level, the central government set up four special economic zones and fourteen open coastal cities in the 1980s. Later, the central government established various national-level economic and technological development zones in many cities in various regions. These areas are granted various types of preferential policies (like preferential tax policy) by the central government and are allowed to have deals with FIEs flexibly. At the same time, the provincial and the municipal governments have also established numerous provincial- or local-level economic and technological development zones and offered special tax incentives to attract FDI. However, it is virtually impossible to have a clear picture of how many provincial- or local-level development zones and what kinds of special tax incentives there are in different regions because there are no complete statistics from publicly available informational sources. We thus focus on the national-level zones.

Following Fung, lizaka and Parker (2002), we adopt two dummy variables. One (SEZD) takes value one if a region has either special economic zone or open coastal city, and zero otherwise. The other one (ETDZD) takes value one if a region has national economic and technological development zone, and zero otherwise. By including these promotion policies, we are able to control for the effects of government incentive policies on FDI location choice and at least partially distinguish between the effects of regional institutional strength and those of government promotion policies.

In the Appendix A2, we present summary statistics for our major regression variables. 


\section{Results}

To investigate the impacts of economic institutions on the location choice of U.S. multinationals in China's various regions, we use the discrete choice model developed by McFadden (1974). The basic premise of the discrete choice model is that the location chosen by a U.S. multinational firm must offer the highest profit over all other possible regions. Let $\pi_{i j t}$ be the profit firm $i$ derives from setting up a manufacturing operation in region $j$ at time $t$. As discussed in Section 2.2, $\pi_{i j t}$ is determined by a list of region $j$ 's characteristics at time $t-1, X_{j t-1}$, including in particular the economic institutions, and $\varepsilon_{i j t}$ is a disturbance term:

$$
\pi_{i j t}=\theta+\beta \cdot X_{j t-1}+\varepsilon_{i j t} .
$$

The probability of firm $i$ locating in region $j$ is given by:

$$
\begin{aligned}
P_{i}(j) & =\operatorname{Pr} o b\left\{\pi_{i j t} \geq \pi_{i k t}\right\} \text { for all } k \neq j \\
& =\operatorname{Pr} o b\left\{\theta+\beta \cdot X_{j t-1}+\varepsilon_{i j t} \geq\left(\theta+\beta \cdot X_{k t-1}+\varepsilon_{i k t}\right)\right\} \text { for all } k \neq j \\
& =\operatorname{Pr} o b\left\{\varepsilon_{i j t}-\varepsilon_{i k t} \geq \beta\left(X_{j t-1}-X_{k t-1}\right)\right\} \text { for all } k \neq j
\end{aligned}
$$

McFadden (1974) shows that, if and only if $\varepsilon_{i j t}$ follows Type I extreme distribution, $P_{i}(j)$ can be further simplified to the following logit expression:

$$
P_{i}(j)=\frac{e^{\beta \cdot X_{j t-1}}}{\sum_{k \in K} e^{\beta \cdot X_{k t-1}}}
$$

where $K$ is the set of location choices faced by firm $i$. And it can then be estimated by the conditional logit method, which has been used extensively in the FDI location literature (e.g., Coughlin, Terza and Arromdee, 1991; Head, Ries and Swenson, 1995). The conditional logit method estimates how each regional characteristic increases or decreases the chances that a region will be chosen rather than all other potential regions available for choice.

We analyze the importance of the four economic institution variables Intellectual Property Rights Protection, Government Intervention in Business Operations, Government Corruption, and Contract Enforcement - one by one, with all the other variables included as control variables. Table 4 presents our main results when regressions are carried out using data from the whole sample period 1993-2001. Intellectual Property Rights Protection has a positive coefficient with statistical significance level of 1\%, while Government Intervention in Business Operations and Government Corruption have negative coefficients both at the $1 \%$ significance level. These results show that U.S. multinationals prefer to invest in those regions of China that 
have a better protection of intellectual property rights, a lower degree of government intervention in business operations and a lower level of government corruption, suggesting the importance of property rights protection in determining the location of FDI. ${ }^{10}$ It is also found that Contract Enforcement has a positive coefficient with the $5 \%$ significance level, implying that the better the contract enforcement of a region the more likely a U.S. multinational may invest in that region. Taken together, our results further confirm the main findings of the emerging economic institution literature that economic institutions matter for investment incentive and economic performance (See, among others, Besley, 1995; Mauro, 1995; La Porta, Lopez-De-Silanes, Shleifer and Vishny, 1999; Acemoglu, Johnson, and Robinson, 2001, 2002). Here our results highlight the impacts of economic institutions, including property rights protection and contract enforcement, in determining the FDI location.

We find that all the four control variables of agglomeration economies generate positive and statistically significant impacts on the FDI location choice of U.S. multinationals. This suggests that U.S. multinationals tend to choose those regions where there are concentration of other U.S. firms engaged in the same industry, clustering of China's indigenous firms of the same industry, and wide market and supplier access. It is interesting that the positive impact of agglomeration of China's indigenous firms is much larger than that of U.S. multinationals: if the agglomeration of China's indigenous firms increases $1 \%$, it raises the probability of investment of U.S. multinationals by $3.01 \%$, while a $1 \%$ rise in the agglomeration of U.S. multinationals boosts the chances of investment of U.S. multinationals by $1.53 \% .{ }^{11}$ This is in contrast to the result of Head, Ries and Swenson (1995) that, when investing in the United States, the Japanese multinationals care more about the clustering of fellow Japanese firms than that of American firms. Also interestingly, the effects of backward agglomeration (supplier access) are much larger than those of forward agglomeration (market access) on the location choice of U.S. multinationals: It can be calculated that a $1 \%$ increment in the ratio of the backward agglomeration indicator will push up the chances of investment of U.S. multinationals by $11.37 \%$, whereas the same increment in the forward agglomeration indicator will raise the probability by $6.43 \%$.

\footnotetext{
${ }^{10}$ It should be pointed out that, while government intervention in business operations could be a second-best substitute for the lack of formal institutions, it is found to be negative for U.S. multinationals as they are bound by law from bribing government officials.

${ }^{11}$ The effects of agglomeration are calculated based on the average of the estimated coefficients of the relevant explanatory variable in regressions 1,2 and 4 of Table 4 . The estimated coefficients in regression 3 are not used because of the much smaller sample size in that regression.
} 
This suggests that supplier access is more important in attracting U.S. firms than market access does. ${ }^{12}$

The other control variables for regional characteristics all exhibit results consistent with both theoretical predictions and existing findings in the literature. Regional average wage rate has a negative effect on U.S. firm entry; this reveals the labor cost effects in U.S. firm location choice. Highway density in a region promotes U.S. firm entry, suggesting that basic infrastructure is one essential factor in luring FDI. Human capital endowment reflected in higher education enrollment also boosts U.S. FDI. This is not surprising because U.S. FDI tends to involve a high level of technology. This is also consistent with the findings of Fung, Iizaka and Parker (2002) and Gao (2005) that regional labor quality significantly affects regional aggregate FDI flows from developed countries including the United States. As expected, the existence of U.S. embassy or consulates facilitates U.S. FDI, as it provides more channels of information sharing. The national government promotion policies produce the expected positive and significant impact on U.S. firm entry.

To test the robustness of our results on economic institutions, we use the alternative measures of Intellectual Property Rights Protection, Government Intervention in Business Operations, and Contract Enforcement from Fan-Wang-Zhu's (2003) China Regional Marketization Indices as described in Section 2.2. Table 5 summarizes the main results of the regressions that are restricted to the subsample 1998-2001 because of the limited availability of the Fan-Wang-Zhu indices. We find that all these three alternative measures of economic institutions have the same qualitative results as in our main regressions (Table 4). The results for the control variables are also similar to those of Table 4, except that the horizontal agglomeration of China's indigenous firms no longer exhibits a larger impact than that of U.S. multinationals. Actually the magnitude of the former effect is a bit smaller than the latter one. However, the backward agglomeration still exerts a positive impact of a larger magnitude than the forward agglomeration does. Other regional characteristics variables present qualitatively equivalent results as in Table 4. In summary, our main results on economic institutions are robust to the alternative measures of the strength of economic institutions.

\section{Conclusion}

Foreign direct investment by multinationals of developed countries has been shown to be important for transition economies as well as developing economies,

\footnotetext{
${ }^{12}$ Amiti and Javorcik (2007) find that the supplier access and market access have sinilar impacts on the changes of FDI flows of China's regions.
} 
for it brings capital, advanced technologies and management know-how. This is especially the case in China, as its transition from a centrally planned economy to a market economy has been driven by its open-door policy (i.e., opening to foreign trade and investment) since 1978. Indeed, many of these developing countries or transition economies have been trying to attract foreign direct investment, mostly through tax incentives.

This paper, however, focuses on the importance of economic institutions in attracting FDI by multinationals. Using a data set of 6,288 U.S. multinationals investing in various regions in China for the period of 1993-2001, we find that U.S. multinationals prefer to invest in those regions that have better protection of intellectual property rights, a lower degree of government intervention in business operations, a lower level of government corruption, and better contract enforcement. Compared with some cross-country studies of the impacts of economic institutions on FDI, our study avoids the problem of controlling for the differences in political system, culture and language, corporate tax policies, and national trade and investment policies across countries. Our data set of firms from the same source country has also help us to avoid the complexity coming from the possible interactions between the identity of foreign investors and local economic institutions.

Our results on the importance of economic institutions for FDI are robust to alternative measures of economic institutions, and to the inclusion of control variables such as those for agglomeration economies, and other traditional factors of FDI location choice. They have policy implications for transition economies as well as developing countries: strengthening economic institutions is one central precondition for attracting FDI inflow.

\section{References}

Acemoglu, Daron and Simon Johnson (2005) "Unbundling Institutions", Journal of Political Economy 113, 949-995

Acemoglu, Daron, Simon Johnson, and James A. Robinson (2001) "The Colonial Origins of Comparative Development: An Empirical Investigation", American Economic Review 91: 1369-1401

Acemoglu, Daron, Simon Johnson, and James A. Robinson (2002) "Reversal of Fortune: Geography and Institutions in the Making of the Modern World Income Distribution", Quarterly Journal of Economics 117: 1231-1294

Amiti, Mary and Beata Smarzynska Javorcki (2007) "Trade costs and location of foreign firms in China", Journal of Development Economics, forthcoming.

Bardhan, Pranab (1997) "Corruption and development: a review of issues", 
Journal of Economic Literature, 35 (3): 1320-46.

Belderbos, René and Martin Carree (2002) "The location of Japanese investments in China: agglomeration effects, keiretsu and firm heterogeneity", Journal of the Japanese and International Economies, 16: 194-211.

Besley, Timothy (1995) "Property Rights and Investment Incentives: Theory and Evidence from Ghana", Journal of Political Economy 103: 903-937.

Boudier-Bensebaa, Fabienne (2005) "Agglomeration economies and location choice: FDI in Hungary", Economics of Transition, 13: 605-628.

Campos, Nauro F. and Yuko Kinoshita (2003) "Why Does FDI Go Where it Goes? New Evidence from the Transition Economies", IMF Working Paper. Chang, Sea-Jin and Sekeun Park (2005) "Types of firms generating network externalities and MNCs' co-location decisions", Strategic Management Journal, 26: 595-615.

Cheng, Leonard K. and Yum K. Kwan (2000) "What are the determinants of the location foreign direct investment? the Chinese experience", Journal of International Economics, 51: 379-400.

Coughlin, Cletus C. , Joseph V. Terza, and Vachira Arromdee (1991) "State characteristics and the location of foreign direct investment within the United States", Review of Economics and Statistics 73, 675-683.

Crozet, Mattieu, Mayer Thierry, and Jean-Louis Muccheilli (2004) "How do firms agglomerate? a study of FDI in France", Regional Science and Urban Economics 34, 27-54.

Duranton, Gilles, and Diego Puga (2004) "Micro-foundations of Urban Agglomeration Economies", in J. Vernon Henderson and Jacques-Francois Thisse (ed.), Handbook of Regional and Urban Economics, Vol. 4: 2063-2118 Fan, Gang, Xiaolu Wang, and Henpeng Zhu (2003) Reports on the Relative Progress of Marketization in Different Regions in China, Economic Science Publishing House, China.

Frye, Timothy and Andrei Shleifer (1997) "The Invisible Hand and the Grabbing Hand", American Economic Review Papers and Proceedings 87: 354358.

Fujita, Masahisa, Paul Krugman, and Anthony J. Venables (2001) The Spatial Economy, MIT Press.

Fung, Kwok Chiu, Hitomi Iizaka, and Stephen Parker (2002) "Determinants of U.S. and Japanese direct investment in China", Journal of Comparative Economics 30, 567-578.

Fung, Kwok Chiu, Hitomi Iizaka, and Alan Siu (2003) "Japanese direct investment in China", China Economic Review 14, 304-315.

Gao, Ting (2005) "Labor quality and the location of foreign direct investment: evidence from China", China Economic Review, 16:274-292. 
Guimarães, Paulo, Octávio Figueiredo, and Douglas Woodward (2000) "Agglomeration and the location of foreign direct investment in Portugal", Journal of Urban Economics, 47: 115-135.

Hall, Robert E. and Charles I. Jones (1999) "Why Do Some Countries Produce So Much More Output per Worker than Others?", Quarterly Journal of Economics 114: 83-116

He, Canfei. (2002) "Information costs, agglomeration economies and the location of foreign direct investment in China", Regional Studies, 36(9), pp. 1029-36.

Head, Keith, and John Ries (1996) "Inter-city competition for foreign investment: static and dynamic effects of China's incentive areas", Journal of Urban Economics, 40: 38-40.

Head, Keith, John Ries, and Deborah Swenson (1995) "Agglomeration benefits and location choice: evidence from Japanese manufacturing investments in the United States", Journal of International Economics, 38: 223-247.

Israel, Chris (2006) "Piracy and Counterfeiting in China", Testimony of U.S. Coordinator for International Intellectual Property Enforcement Before the US-China Economic and Security Review Commission, June 7.

Knack, Stephen and Philip Keefer (1995) "Institutions and Economic Performance: Cross-Country Tests Using Alternative Institutional Measures", Economics and Politics, 7: 207-227.

Knack, Stephen and Philip Keefer (1997) "Dose Social Capital Have an Economic Payoff? A Cross-Country Investigation", Quarterly Journal of Economics 112: 1251-1288.

Krugman, Paul (1991) "Increasing returns and economic geography", Journal of Political Economy, 99:483-99.

Krugman, Paul and Anthony J. Venables (1995) "Globalization and the Inequality of Nations", Quarterly Journal of Economics, 110: 857-880.

La Porta, Rafael, Florencio Lopez-de-Silanes, Andrei Shleifer and Robert Vishny (1999) "The Quality of Government", Journal of Law, Economics and Organization 15: 222-279.

Mauro, Paolo (1995) "Corruption and Growth", Quarterly Journal of Economics 110: 681-712.

McFadden, Daniel (1974) "Conditional Logit Analysis of Qualitative Choice Behavior", in Paul Zarembka (ed.), Frontiers in Econometrics, New York: Academic Press, 105-142.

Pande, Rohini and Christopher Udry (2005) "Institutions and Development: A View from Below", working paper, Yale University.

Porter, Michael (1998) "Clustering and the new economics of competition", Harvard Business Review, 76(6): 77-90. 
Shleifer, Andrei and Robert W. Vishny (1999) Grabbing Hand: Government Pathologies and Their Cures, Harvard University Press.

Stratford, Timothy P. (2006) "China's Enforcement of Intellectual Property Rights and the Dangers of the Movement of Counterfeit and Pirated Goods into the United States", Prepared Statement of Assistant U.S. Trade Representative Before the U.S.-China Economic and Security Review Commission, June 7.

Wei, Shang-Jin (2000a) "How taxing is corruption on international investors?", Review of Economics and Statistics, 82(1): 1-11.

Wei, Shang-Jin (2000b) "Local corruption and global capital flows", Brookings Papers on Economic Activity, 2: 303-54.

World Bank (1997) China Engaged: Integration with the Global Economy, Washington, D.C.: World Bank.

Venables, Anthony J. ""Equilibrium Locations of Vertically Linked Industries", International Economic Review, 37: 341-359. 
Table 1: Entry of U.S. Manufacturing Multinationals into China by Year

\begin{tabular}{|c|rr|}
\hline YEAR & $\begin{array}{c}\text { Number } \\
\text { of New } \\
\text { Entry }\end{array}$ & $\begin{array}{c}\text { Accumulated } \\
\text { Number of Entry }\end{array}$ \\
\hline 1982 & 3 & 3 \\
1983 & 2 & 5 \\
1984 & 6 & 11 \\
1985 & 17 & 28 \\
1986 & 20 & 48 \\
1987 & 25 & 73 \\
1988 & 58 & 131 \\
1989 & 68 & 199 \\
1990 & 88 & 287 \\
1991 & 205 & 492 \\
1992 & 735 & 1227 \\
1993 & 1170 & 2397 \\
1994 & 751 & 3148 \\
1995 & 890 & 4038 \\
1996 & 599 & 4637 \\
1997 & 624 & 5261 \\
1998 & 709 & 5970 \\
1999 & 709 & 6679 \\
2000 & 13 & 6692 \\
2001 & 829 & 7521 \\
\hline
\end{tabular}

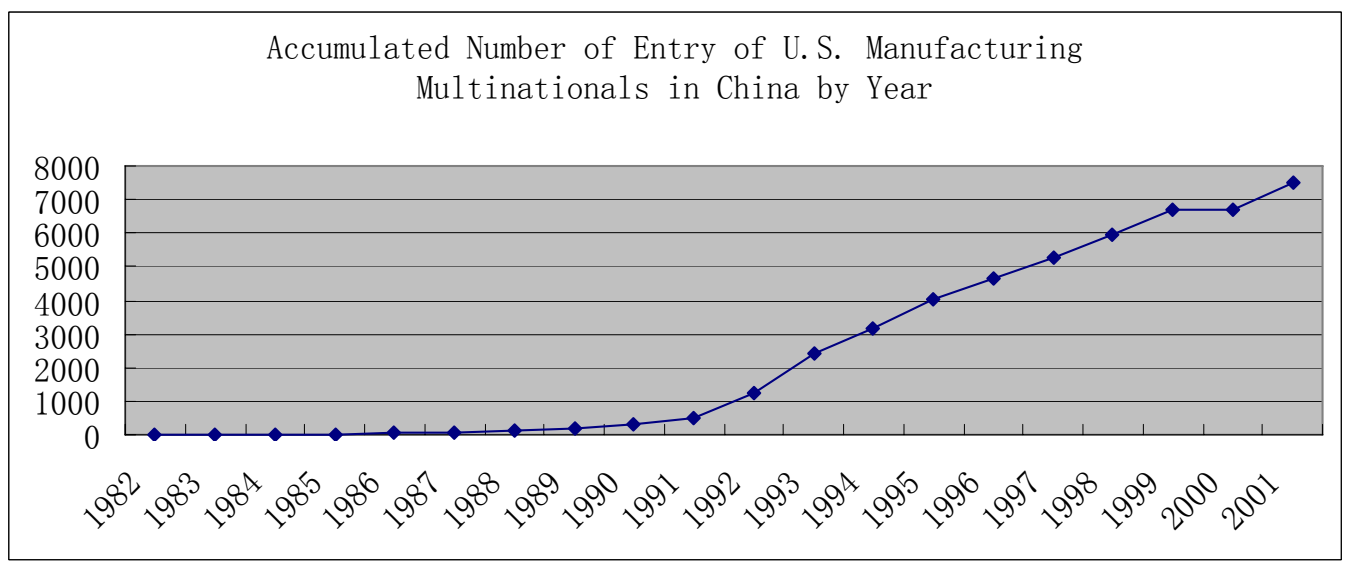


Table 2: Geographic Distribution of Investment by U.S. Manufacturing Multinationals in China (Year 2001)

\begin{tabular}{|lrr|lrr|}
\hline Region & Number & Percentage & Region & Number & Percentage \\
\hline Beijing & 594 & 7.90 & Henan & 133 & 1.77 \\
Tianjin & 401 & 5.33 & Hubei & 126 & 1.68 \\
Hebei & 275 & 3.66 & Hunan & 71 & 0.94 \\
Shanxi & 71 & 0.94 & Guangdong & 650 & 8.64 \\
Inner Mongolia & 56 & 0.74 & Guangxi & 57 & 0.76 \\
Liaoning & 506 & 6.73 & Hainan & 13 & 0.17 \\
Jilin & 92 & 1.22 & Sichuan & 179 & 2.38 \\
Heilongjiang & 100 & 1.33 & Guizhou & 24 & 0.32 \\
Shanghai & 989 & 13.15 & Yunnan & 43 & 0.57 \\
Jiangsu & 1143 & 15.20 & Shaanxi & 96 & 1.28 \\
Zhejiang & 657 & 8.74 & Gansu & 23 & 0.31 \\
Anhui & 151 & 2.01 & Qinghai & 4 & 0.05 \\
Fujian & 154 & 2.05 & Ningxia & 10 & 0.13 \\
Jiangxi & 53 & 0.70 & Xinjiang & 23 & 0.31 \\
Shandong & 827 & 11.00 & & & \\
\hline
\end{tabular}

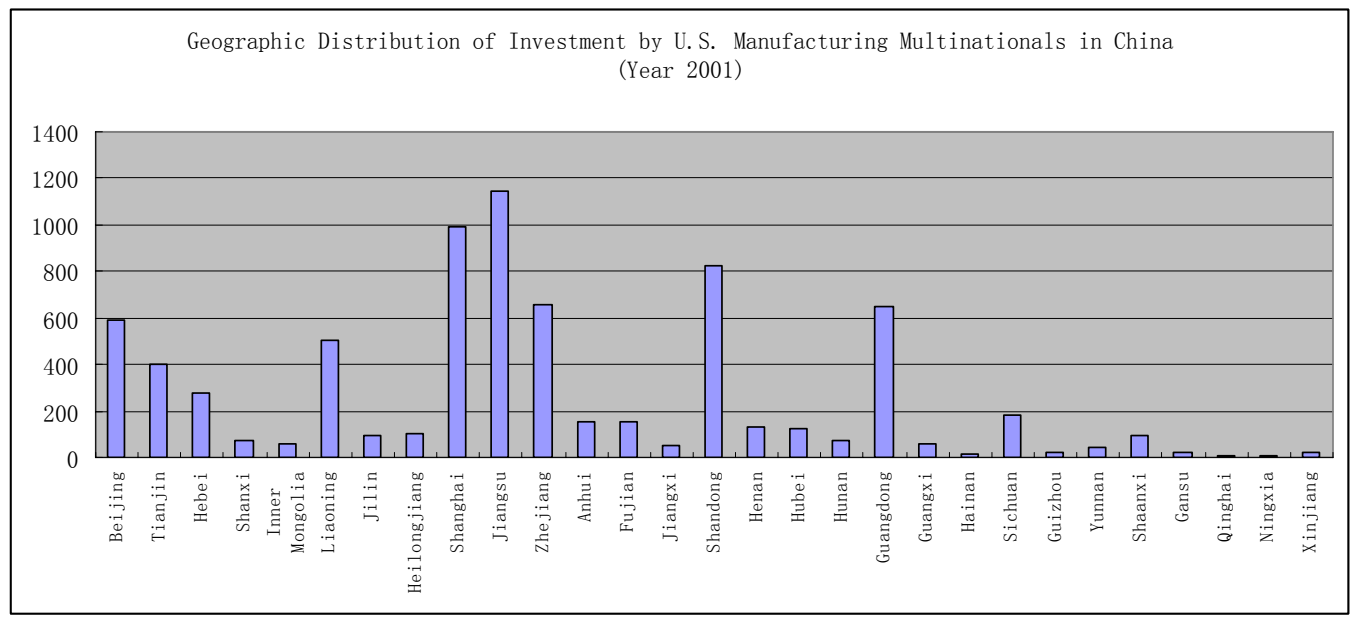


Table 3: Indices of Economic Institutions in China's Regions (Year 2000)

\begin{tabular}{|c|c|c|c|c|}
\hline Region & $\begin{array}{c}\text { Intellectual } \\
\text { Property Rights } \\
\text { Protection }\end{array}$ & $\begin{array}{l}\text { Government Intervention } \\
\text { in Business Operations }\end{array}$ & Government Corruption & Contract Enforcement \\
\hline Beijing & 1.45 & 0.10 & 0.65 & 0.24 \\
\hline Tianjin & 0.48 & 0.11 & 0.67 & 0.17 \\
\hline Hebei & -0.87 & 0.06 & 0.54 & 0.22 \\
\hline Shanxi & -1.23 & 0.02 & 0.62 & 0.10 \\
\hline Inner Mongolia & -1.12 & 0.04 & 0.56 & 0.28 \\
\hline Liaoning & 0.13 & 0.09 & 0.63 & 0.18 \\
\hline Jilin & -0.50 & 0.10 & 0.76 & 0.10 \\
\hline Heilongjiang & -0.49 & 0.08 & 0.65 & 0.20 \\
\hline Shanghai & 0.88 & 0.07 & 0.37 & 0.25 \\
\hline Jiangsu & -0.15 & 0.11 & 0.44 & 0.23 \\
\hline Zhejiang & 0.47 & 0.10 & 0.45 & 0.22 \\
\hline Anhui & -1.40 & 0.15 & 0.63 & 0.29 \\
\hline Fujian & -0.14 & 0.10 & 0.51 & 0.33 \\
\hline Jiangxi & -1.35 & 0.07 & 0.54 & 0.20 \\
\hline Shandong & -0.27 & 0.05 & 0.52 & 0.32 \\
\hline Henan & -1.21 & 0.04 & 0.52 & 0.15 \\
\hline Hubei & -1.01 & 0.17 & 0.39 & 0.16 \\
\hline Hunan & -0.92 & 0.08 & 0.70 & 0.30 \\
\hline Guangdong & 0.60 & 0.05 & 0.60 & 0.22 \\
\hline Guangxi & -1.33 & 0.14 & 0.55 & 0.23 \\
\hline Hainan & -0.90 & 0.14 & 0.81 & 0.26 \\
\hline Sichuan & -0.96 & 0.13 & 0.68 & 0.27 \\
\hline Guizhou & -1.60 & 0.18 & 0.88 & 0.27 \\
\hline Yunnan & -1.26 & 0.10 & 0.59 & 0.31 \\
\hline
\end{tabular}




\begin{tabular}{l|llll} 
Shaanxi & -0.90 & 0.09 & 0.47 & 0.23 \\
Gansu & -1.65 & 0.10 & 0.67 & 0.41 \\
Qinghai & -1.49 & 0.00 & 0.45 & 0.30 \\
Ningxia & -0.92 & 0.08 & 0.45 & 0.17 \\
Xinjiang & -0.99 & 0.14 & 0.59 & 0.35 \\
\hline
\end{tabular}


Table 4: Economic Institutions and FDI Location Choice (Main Regression Results)

\begin{tabular}{|c|c|c|c|c|}
\hline & 1 & 2 & $3^{\text {a }}$ & 4 \\
\hline \multicolumn{5}{|l|}{ Economic Institutions } \\
\hline $\begin{array}{l}\text { Intellectual Property } \\
\text { Right Protection } \\
\text { Government Intervention in } \\
\text { Business Operations } \\
\text { Government Corruption } \\
\text { Contract Enforcement }\end{array}$ & $\begin{array}{l}0.344 * * * \\
(0.036)\end{array}$ & $\begin{array}{c}-3.597 * * * \\
(0.588)\end{array}$ & $\begin{array}{c}-1.691 * * * \\
\quad(0.244)\end{array}$ & $\begin{array}{l}0.784 * * \\
(0.337)\end{array}$ \\
\hline \multicolumn{5}{|l|}{ Agglomeration } \\
\hline $\begin{array}{l}\text { Agglomeration US } \\
\text { Agglomeration Domestic } \\
\text { Backward Agglomeration } \\
\text { Forward Agglomeration }\end{array}$ & $\begin{array}{r}1.598 * * * \\
(0.091) \\
2.974 * * * \\
(0.219) \\
11.061 * * * \\
(0.845) \\
5.398 * * * \\
(0.763)\end{array}$ & $\begin{array}{r}1.584 * * * \\
(0.092) \\
3.094 * * * \\
(0.220) \\
11.932 * * * \\
(0.844) \\
6.406 * * * \\
(0.754)\end{array}$ & $\begin{array}{r}2.736 * * * \\
(0.187) \\
2.679 * * * \\
(0.355) \\
9.042 * * * \\
(1.425) \\
6.180 * * * \\
(1.202) \\
\end{array}$ & $\begin{array}{r}1.582 * * * \\
(0.092) \\
3.121 * * * \\
(0.220) \\
11.778 * * * \\
(0.845) \\
6.657 * * * \\
(0.752)\end{array}$ \\
\hline \multicolumn{5}{|l|}{ Other Controlled Variables } \\
\hline $\begin{array}{l}\text { Wage } \\
\text { Infrastructure } \\
\text { Education }\end{array}$ & $\begin{array}{r}-1.115 * * * \\
(0.086) \\
0.474 * * * \\
(0.042) \\
0.201 * * * \\
(0.041)\end{array}$ & $\begin{array}{r}-1.030 * * * \\
(0.086) \\
0.589 * * * \\
(0.040) \\
0.436 * * * \\
(0.030)\end{array}$ & $\begin{array}{r}-1.260 * * * \\
(0.145) \\
0.563 * * * \\
(0.065) \\
0.367 * * * \\
(0.063)\end{array}$ & $\begin{array}{r}-1.066 * * * \\
(0.056) \\
0.630 * * * \\
(0.040) \\
0.482 * * \\
(0.029)\end{array}$ \\
\hline $\begin{array}{l}\text { Presence of US embassy or } \\
\text { consulates }\end{array}$ & $\begin{array}{l}0.329 * * * \\
\quad(0.038)\end{array}$ & $\begin{array}{r}0.400 * * * \\
(0.038)\end{array}$ & $\begin{array}{l}0.627 * * * \\
\quad(0.067)\end{array}$ & $\begin{array}{r}0.379 * * * \\
\quad(0.038)\end{array}$ \\
\hline SEZD & $\begin{array}{c}0.538 * * * \\
(0.043)\end{array}$ & $\begin{array}{r}0.496 * * * \\
\quad(0.045)\end{array}$ & $\begin{array}{r}0.590 * * * \\
\quad(0.070)\end{array}$ & $\begin{array}{r}0.540 * * * \\
(0.044)\end{array}$ \\
\hline ETDZD & $\begin{array}{c}0.223 * * * \\
(0.050)\end{array}$ & $\begin{array}{c}0.294 * * * \\
(0.051) \\
\end{array}$ & $\begin{array}{c}0.296 * * * \\
(0.087) \\
\end{array}$ & $\begin{array}{r}0.260 * * * \\
(0.050) \\
\end{array}$ \\
\hline No. of choosers & 6,288 & 6,288 & 2,259 & 6,288 \\
\hline No. of choices & 29 & 29 & 29 & 29 \\
\hline Pseudo R2 & 0.1881 & 0.1868 & 0.2075 & 0.1860 \\
\hline LR chi2(11) & 7965.75 & 7909.57 & 3156.72 & 7876.84 \\
\hline
\end{tabular}

Standard errors are reported in parentheses. *, **, *** represent the significance at $10 \%, 5 \%, 1 \%$ level, respectively.

${ }^{\mathrm{a}}$ The number of choosers on the corruption index regression is reduced to 1998-2001 due to the availability of the index. 
Table 5: Economic Institutions and FDI Location Choice

\section{(Robustness Check)}

\begin{tabular}{|c|c|c|c|}
\hline & 1 & 2 & 3 \\
\hline \multicolumn{4}{|l|}{ Economic Institutions } \\
\hline $\begin{array}{l}\text { Intellectual Property } \\
\text { Right Protection } \\
\text { Government Intervention } \\
\text { in Business Operations } \\
\text { Contract Enforcement }\end{array}$ & $\begin{array}{l}0.016 * \\
(0.010\end{array}$ & $\begin{array}{c}0.026 * * \\
(0.012)\end{array}$ & $\begin{array}{r}0.093 * * * \\
(0.021) \\
\end{array}$ \\
\hline \multicolumn{4}{|l|}{ Agglomeration } \\
\hline $\begin{array}{l}\text { Agglomeration US } \\
\text { Agglomeration Domestic } \\
\text { Backward Agglomeration } \\
\text { Forward Agglomeration }\end{array}$ & $\begin{array}{r}2.925 * * * \\
(0.186) \\
2.524 * * * \\
(0.356) \\
10.836 * * * \\
(1.389) \\
6.578 * * * \\
(1.198) \\
\end{array}$ & $\begin{array}{r}2.894 * * * * \\
(0.186) \\
2.618 * * * \\
(0.356) \\
10.258 * * * \\
(1.409) \\
6.534 * * * \\
(1.197) \\
\end{array}$ & $\begin{array}{r}2.760 * * * \\
(0.189) \\
2.616 * * * \\
(0.356) \\
10.660 * * * \\
(1.397) \\
7.531 * * * \\
(1.200) \\
\end{array}$ \\
\hline \multicolumn{4}{|c|}{ Other Controlled Variables } \\
\hline $\begin{array}{l}\text { Wage } \\
\text { Infrastructure } \\
\text { Education }\end{array}$ & $\begin{array}{r}-1.052 * * * \\
(0.142) \\
0.509 * * * \\
(0.064) \\
0.430 * * * \\
(0.063)\end{array}$ & $\begin{array}{r}-1.001 * * * \\
(0.142) \\
0.505 * * * \\
(0.065) \\
0.424 * * * \\
(0.062)\end{array}$ & $\begin{array}{r}-1.330 * * * \\
(0.158) \\
0.416 * * * \\
(0.067) \\
0.160 * \\
(0.083)\end{array}$ \\
\hline $\begin{array}{l}\text { Presence of US embassy or } \\
\text { consulates }\end{array}$ & $\begin{array}{r}0.470 * * * \\
(0.065)\end{array}$ & $\begin{array}{r}0.443 * * * \\
(0.069)\end{array}$ & $\begin{array}{r}0.546 * * * \\
(0.064)\end{array}$ \\
\hline $\begin{array}{l}\text { SEZD } \\
\text { ETDZD }\end{array}$ & $\begin{array}{r}0.671 * * * \\
(0.070) \\
0.141 * * * \\
(0.087)\end{array}$ & $\begin{array}{r}0.671 * * * \\
(0.070) \\
0.145 * * * \\
(0.086)\end{array}$ & $\begin{array}{r}0.799 * * * \\
(0.075) \\
0.197 * * \\
(0.086)\end{array}$ \\
\hline No. of choosers & 2,259 & 2,259 & 2,259 \\
\hline No. of choices & 29 & 29 & 29 \\
\hline Pseudo R2 & 0.2045 & 0.2046 & 0.2056 \\
\hline LR chi2(11) & 3110.93 & 3112.46 & 3128.33 \\
\hline
\end{tabular}

Standard errors are reported in parentheses. ${ }^{*}, * *, * * *$ represent the significance at $10 \%, 5 \%, 1 \%$ level, respectively. 


\section{Appendix A1: Description of Other Control Variables for Regional Characteristics in China}

\begin{tabular}{|c|c|c|}
\hline Variable & Description & Data Source \\
\hline Wage & the logarithm of the average manufacturing wage (Unit: Yuan) & China Statistical Yearbook, various issues \\
\hline Infrastructure & the logarithm of the highway density (Unit: km/sq. km) & China Statistical Yearbook, various issues \\
\hline Education & the logarithm of the ratio of employment with college degree or above & China Statistical Yearbook, various issues \\
\hline $\begin{array}{l}\text { Presence of US embassy or } \\
\text { consulates }\end{array}$ & $\begin{array}{l}\text { a dummy variable which equals one when the region has the US embassy or } \\
\text { consulates }\end{array}$ & $\begin{array}{l}\text { History of the diplomatic establishment between China and } \\
\text { United States 1786-1994, Huang Gang, } 1995 \text { Taiwan }\end{array}$ \\
\hline SEZD & $\begin{array}{l}\text { a dummy variable which equals one when the region has a special economic zone* } \\
\text { or an open coastal city**}\end{array}$ & $\begin{array}{l}\text { Comprehensive statistical data and materials on } 50 \text { years of } \\
\text { New China 1949-1999, National Bureau of Statistics of } \\
\text { China, } 1999\end{array}$ \\
\hline ETDZD & $\begin{array}{l}\text { a dummy variable which equals one when the region has an economic and } \\
\text { technological development zone }{ }^{\star * *}\end{array}$ & Ministry of Commerce of China \\
\hline
\end{tabular}

* Special economic zones: Zhuhai, Shenzhen, and Shantou in Guangdong Province, Xiamen in Fujian Province, and Hainan Province.

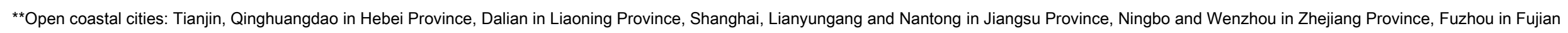
Province, Yantai and Tsingtao in Shandong Province, Guangzhou and Zhanjiang in Guangdong Province, and Beihai in Guangxi Province.

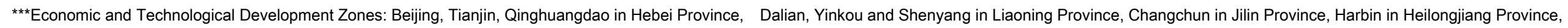

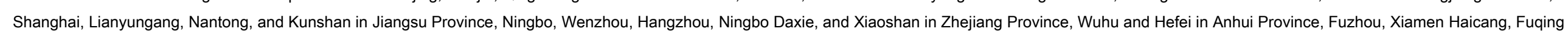

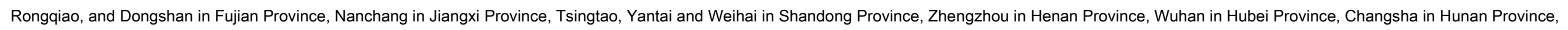

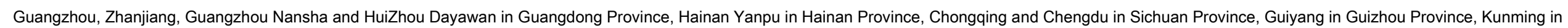


Yunnan Province, Xi'an in Shaanxi Province, Xining in Qinghai Province, and Urumuqi and Shihezi in the Xinjiang Uygur Autonomous Region 


\section{Appendix A2: Summary Statistics of Variables}

\begin{tabular}{|c|c|c|c|c|}
\hline Variable & Mean & Std. Dev. & Min & Max \\
\hline \multicolumn{5}{|l|}{ Economic Institutions } \\
\hline $\begin{array}{lll}\text { Intellectual } & \text { Property } & \text { Rights } \\
\text { Protection } & & \end{array}$ & -1.152 & 0.897 & -2.905 & 1.653 \\
\hline $\begin{array}{l}\text { Government Intervention in Business } \\
\text { Operations }\end{array}$ & 0.045 & 0.039 & 0 & 0.181 \\
\hline Government Corruption & 0.573 & 0.116 & 0.333 & 0.879 \\
\hline Contract Enforcement & 0.117 & 0.083 & 0.022 & 0.500 \\
\hline $\begin{array}{l}\text { Intellectual Property } \quad \text { Rights } \\
\text { Protection (Fan-Wang-Zhu's index) }\end{array}$ & 1.833 & 2. 117 & 0 & 11.77 \\
\hline $\begin{array}{l}\text { Government Intervention in Business } \\
\text { Operations (Fan-Wang-Zhu' s index) }\end{array}$ & 6. 181 & 2. 688 & 0 & 10 \\
\hline $\begin{array}{l}\text { Contract Enforcement (Fan-Wang-Zhu's } \\
\text { index) }\end{array}$ & 2. 322 & 2. 284 & 0 & 11.39 \\
\hline \multicolumn{5}{|l|}{ Agglomeration } \\
\hline Agglomeration US & 0.0332 & 0.0833 & 0 & 1 \\
\hline Agglomeration Domestic & 0.0343 & 0.0508 & 0 & 1 \\
\hline Backward Agglomeration & 0.0188 & 0.0200 & 0.0000602 & 0.271 \\
\hline Forward Agglomeration & 0.0255 & 0.0247 & 0.0000206 & 0.364 \\
\hline \multicolumn{5}{|l|}{ Other Controlled Variables } \\
\hline Wage & 8. 456 & 0.430 & 7. 681 & 9.752 \\
\hline Infrastructure & -1.595 & 0.845 & -4.159 & -0.212 \\
\hline Education & 1.001 & 0.660 & -0.223 & 3. 135 \\
\hline Presence of US embassy or consulates & 0.172 & 0.378 & 0 & 1 \\
\hline SEZD & 0.375 & 0.484 & 0 & 1 \\
\hline ETDZD & 0.529 & 0.499 & 0 & 1 \\
\hline
\end{tabular}

